\title{
ENTREPRENEURSHIP EDUCATION IN HIGHER EDUCATION
}

\section{Fahmi Idris}

State University of jakarta

Email: idrisfahmiunj@gmail.com

\begin{abstract}
Unemployment, economic growth, and low entrepreneurial ratio has become current problem in Indonesia. Entrepreneurship education is an important form of intervention to overcome these problems.This article reviews the concepts and developments in the field of entrepreneurship education in the literature. Furthermore, this study critically examines the development of entrepreneurship education in Indonesia and implement the existing theoretical framework to recommend a number of improvements that can be taken by higher education and other stakeholders to enhance the quality of entrepreneurship education in Indonesia.
\end{abstract}

Keywords: Entrepreneurship, entrepreneurship education, higher education, critical theory

\section{INTRODUCTION}

Indonesia has a very high unemployment rate, low economic growth, and low total entrepreneurial activity. Although statistic data show that the open unemployment rate in 2006-2018 is decreasing, it still higher than the late 1980 era rate. As seen in Figure 1, from at least 1986-1993, the unemployment rate in Indonesia only reached around 2\%, while in 2013-2018, the unemployment rate in Indonesia was not lower than 5\%.

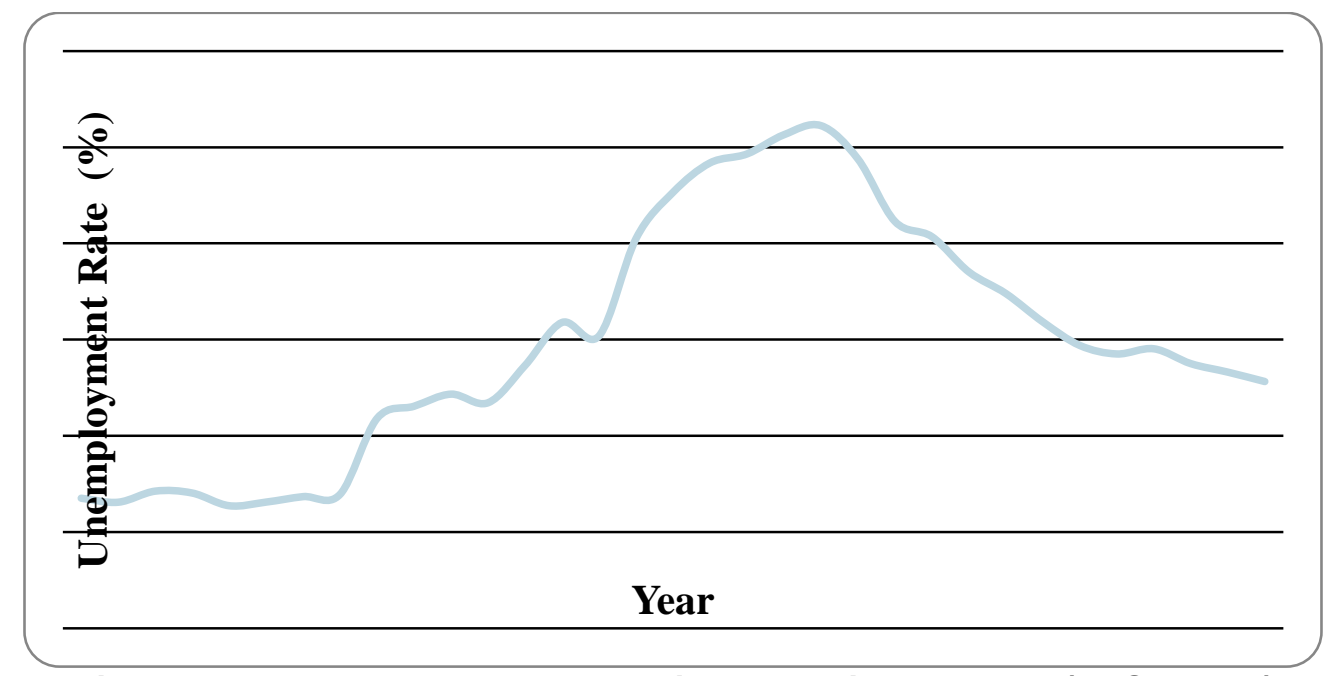

Figure 1: Open Unemployment Rate in Indonesia 1986-2018 (BPS, 2018b)

The same thing applied in economic growth rate where 2014-2018 era rate was actually lower than the 2009-2013 era. In 2014-2018, average economic growth was $4.96 \%$ per yearwhile in the $2009-2013$ era was $5.84 \%$ per year.Not to mention when compared with economic growth in 1992-1996 which reached $7.20 \%$ per year. 


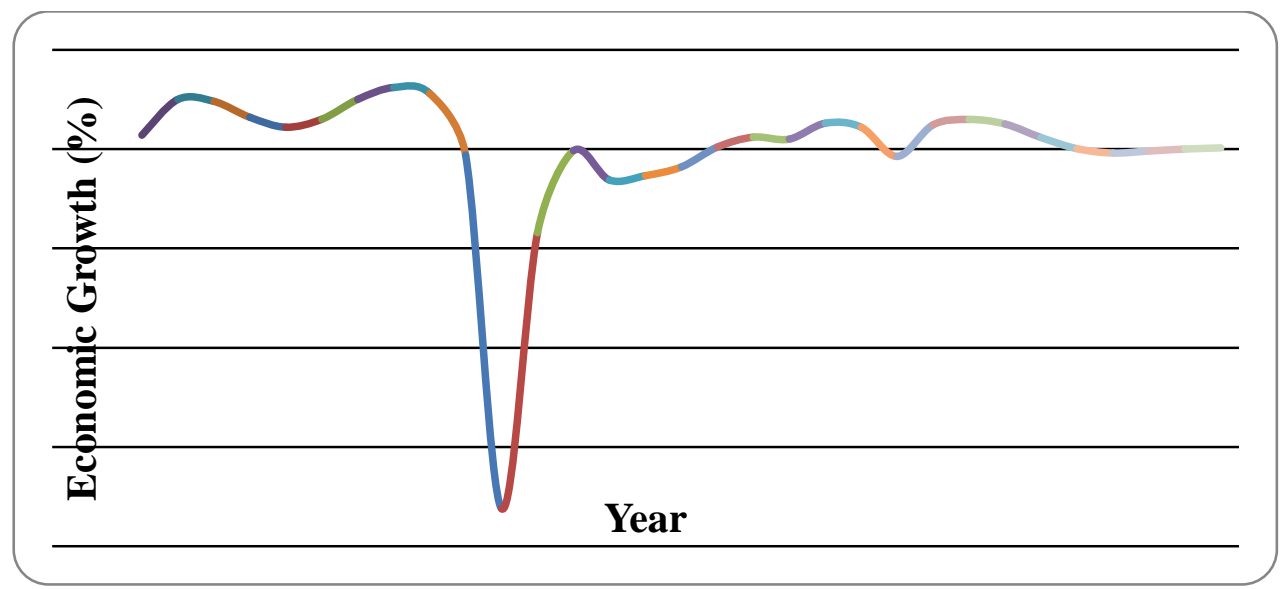

Figure 2: Development of Indonesia Economic Growth 1986-2018 (BPS, 2018a)

In the other hand, the growth of entrepreneurial activities is quite encouraging. Entrepreneurship which was only carried out by $0.24 \%$ of Indonesians in 2009 , rise to $1.56 \%$ in 2014 (Mopangga, 2014). In 2017, the percentage of entrepreneurship has reached $3.1 \%$ of the total population. It is relatively higher than the minimum threshold of the proportion of entrepreneurs in developed countries which is $2.0 \%$ (Kominfo, 2017). However, this percentage is still far behind compared to other developed countries such as Malaysia (5\%) (Tempest, 2017), United States (12\%), or India (7\%) (Berita Satu, 2016). These are a big challenge for the government and the private sector because of the impact on the whole national economy. High unemployment has an impact on low productivity while low economic growth will lead to a decline in welfare of Indonesianfamilies. The low level of entrepreneurship leads to an undeveloped economy as well.

One solution that can be taken to overcome the problem of unemployment, economic growth, and low local entrepreneurial activities is by providing entrepreneurship education in universities. Good entrepreneurship education can give a positive impact on the creation of new jobs (Hindle, 2007; B. Jones \&Iredale, 2010), the development of key competencies is important for economics (Lackus, Lundqvist, and Middleton, 2016), the ability to overcome social problems (Rae, 2010; Volkmann et al., 2009), supporting local and national economic growth (Kuratko, 2005), and even increasing the involvement of students or students in education in their schools / universities (Moberg, 2014).

This needs to be done at the higher education level because compared to hight school students, college students are better prepared to work independently and able to be given the responsibility for contributing to the economy for themselves. Higher education level students have the cognitive capacity which is importantly needed as competencies in entrepreneurship education.

After 1998 reformation, the government's efforts to inisiate entrepreneurship education in universities have intensified. The implementation of Presidential Instruction No. 4 of 1995 concerning the National Movement to Promote and Cultivate Entrepreneurship was a bit slowed down by the 1997 economic crisis. Afterwards, various entrepreneurship education programs began to be implemented in various universities in Indonesia, starting from a one-day lecture to independent courses, which is required by all students. Some even have entrepreneurship study programs for example, UI, ITB which opened this program since 2013.

However, up until now, problems such as unemployment, low economic growth, and low levels of entrepreneurship as found above are still continue to grow. It shows that the efforts that have been made have not produced the expected results yet. At this point some basic questions arise: is a current entrepreneurship education in Indonesian still has a low quality? Does it need to add curriculum both in quantity and quality? Are there new things that unnotice when entrepreneurship education in universities in Indonesia was developed? The following review aims to provide guidance on what needs to be reviewed from the current entrepreneurship education system both locally and nationally in Indonesia. 


\section{METHODOLOGY}

This study reviewed a various development around the concept of entrepreneurship education in the literature. Furthermore, a critical approach method is given to review the situation of entrepreneurship education in Indonesia. Entrepreneurship literatur review is used to formulate the recommendation concerning entrepreneurship education in Indonesia. The critical approach method is still rarely used in the field of entrepreneurship (Perren \& Jennings, 2005). Therefore, the application of this method to entrepreneurship education in Indonesia is able provide a new picture in the study of entrepreneurship.

\section{RESULT AND DISCUSSION}

The researchers have proposed many notions of entrepreneurship education. Some viewd it as "specialized knowledge instilled in learners about the characteristics of risk taking, innovation, arbitration, and coordination of factors of production with the aim of creaeting new products or services for new users and those already in human society" (Minniti and Lévesque, 2008). Heinonen and Poikkijoki (2006) defines entrepreneurship education as an activity that aims to develop entrepreneurs and increase their understanding and knowledge of entrepreneurs and companies.

Another paradigm viewed entrepreneurship education as a "formal or informal learning that encourages students to get the ability to recognize, review, and capture opportunities available in the environment other than to gain skills" (C. Jones and English, 2004). Bin Yusoff, Zainol, and Bin Ibrahim (2015) practically distinguishing entrepreneurial education from entrepreneurship education, where they interpret entrepreneurship education as "a curriculum designed to instill knowledge-based education and the theoretical context of entrepreneurship in an artificial environment", while education entrepreneurship is "a curriculum that emphasizes the development and improvement of tasit knowledge (experience-based through real practice) on students".

Although there are a lot of definitions, entrepreneurship education can be understood as a program with the aim of encouraging awareness and action to make entrepreneurship a career goal, whether it is generating new business or developing an existing business. Entrepreneurship education provides the ability for individuals to be able to recognize business opportunities as well as equip them with the knowledge, skills, and attitudes that are important to exploit these business opportunities.

The distinctive characteristics of entrepreneurship education can be seen from the contents ofits curriculum. According to Fayolle, Gailly, \&Lassas-Clerc (2006), good entrepreneurship education must contain five things: know-why, know-how, know-who, know-when, and know-what. That is, entrepreneurship education teaches someone to know why, how, who, when, and what. Know why means that someone who gets an entrepreneurship education must have the attitudes, values and motivations that enable him to know why he must become an entrepreneur. Know how relates to the ability to entrepreneurship. Know who related to social skills, both short and long term. Know when it is related to intuition about when to start a business, which in turn, related to the ability to see opportunities. Know what means knowledge of both business knowledge and product knowledge.

Because of its broad content, it is not surprising that entrepreneurial education emerged in various types. Liñán (2004) observed that there were four types of entrepreneurship education implemented in Spain. First is an education to starts a business. This education contains a content is limited to business planning. Second is education on entrepreneurial awareness. This kind of entrepreneurship education focused more on analyzing the role of entrepreneurial agents in economic development and highlighting its urgency. Theoretically, education to starts a business focused more to the technical and 
business feasibility aspects to run a business, which means that the students themselves have the intention to become entrepreneurs. Meanwhile entrepreneurial awareness education is more on the social feasibility aspects of a business so that a student becomes aware, knows about entrepreneurship, and intends to become an entrepreneur.

Third kind of entrepreneurship education is entrepreneurial dynamism education. This education is focused on the phase after the business exists. It aims to make the business grow and overcome various challenges. Fourth, advance entrepreneurship education. This kind of education is related to long-term aspects and is directed at entrepreneurs who have long experience in business.

The entrepreneurship education division is also not limited to the stages of one's entrepreneurship but also to the contextual aspects. Entrepreneurship education textbooks are often too general, it failed to implicate real new possibilities for doing business (Blenker, Dreisler, and Kjeldsen, 2006). Therefore, entrepreneurship education can also be developed contextually and specifically in certain fields. It can be bound to a place, certain demographic groups, certain economic fields, and so on. For example, entrepreneurship education can be packaged specifically into entrepreneurship education in Jakarta, online business entrepreneurship education, agricultural entrepreneurship, entrepreneurship for a technician, and so on. Education with this contextual curriculum indeed narrows the business oportunity, but is more focused and if given to the appropriate student, it will provide more tangible and relevant actuality to the background of the student.

Education can be devided into formal and informal, it also applied to the entrepreneurship education. Higher education in entrepreneurship is a formal form of education, therefore the pseudo-informal aspects of entrepreneurship is able to be given. For example, students can be invited to study entrepreneurship by taking them to a company or small and successful medium-sized business to conduct interviews, observation, or even become an apretince with real experienced people. Even the expert canteen owner on campus can be a source of informal entrepreneurship education for students. The knowledge provided by field people is certainly informal because it is unstructured and may not have an explicit theoretical basis. However, because entrepreneurship is an open field, the tasit and contextual knowledge is also needed to be able to enrich education as well as the impact of education.

There are many entrepreneurship education models that can be developed in accordance with the context, students, and stages of entrepreneurship. One model is quite relevant forbeginner in entrepreneurship education. This model was developed by Zupan and Nabergoj (2016). Figure 3 shows this education model.

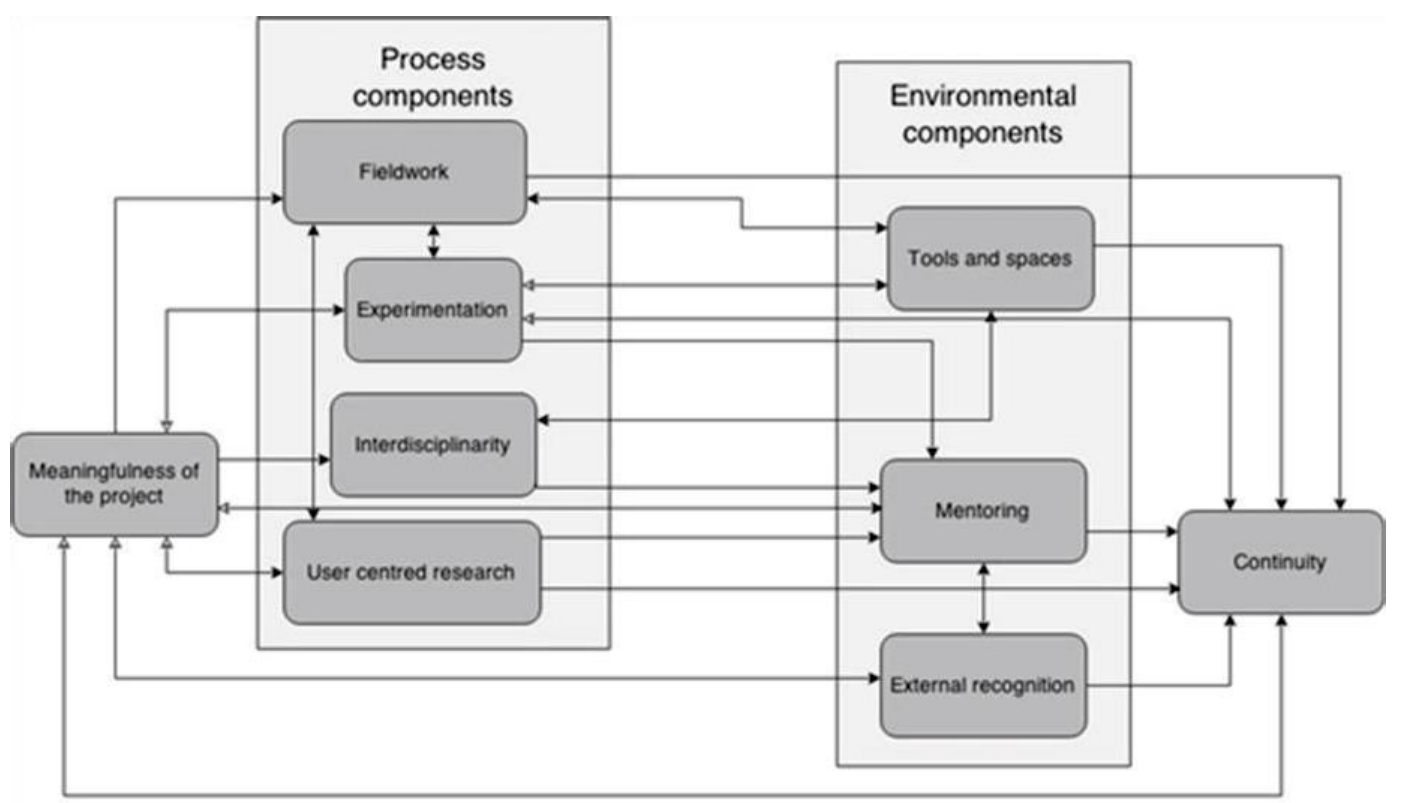

Figure 3: Entrepreneurship Education Model (Zupan \& Nabergoj, 2016) 
The model showed that the ultimate goal of entrepreneurship education is continues, in term that business can emerge and generate sustainable benefits for entrepreneurs. There are three things that determine the continuity of education. First is the significance of the project. This effectiveness related to entrepreneurial awareness of each student. It depends on five things: experimentation, mentoring, results of market research (users), external recognition, and sustainability of previous businesses. After that, the continuity of education also determine by process components. The process component includes field studies, experimentation, interdisciplinarity and market research. Lastly, the component of the environment or context can also determine the continuity of education. This component includes tools and space, mentoring process, and external recognition. All of these variables are interrelated and therefore, need to be provided thoroughly by universities that teach entrepreneurship education.

Process component can be easily provided by the colleges as a part of higher education curriculum. For example, interdisciplinarity is common in higher education because experts from broad research field geather in the university. Each experst are able to contribute various aspect of entrepreneurship from their educational background. Field studies can be conducted through collaboration with industries, MSMEs, or business practitioners and entrepreneurs. In addition, student can also conduct experiment and market study. Infrastructure is a challenging part at universities environment. Higher education institutions need to provide tools, space, mentors, and also recognition of student entrepreneurship profit sharing. Many funding programs have been implemented in higher education such as PMW (Entrepreneurial Student Program) and PSW (Entrepreneurial Bachelor Program). But mentoring requires one or more dedicated lecturers to support student in running their business.

Entrepreneurship education is one of the important manifestations of economic democracy as stated in article 33 of the 1945 Constitution paragraph 4. According to Ruslina (2012), economic democracy must be realized in the form of participation and economic emancipation. That means the community has the right to participate in the economy, including in the form of creating its own employment through entrepreneurship. Economic democracy favors poor and weak people so that they get special attention and treatment in order to experience empowerment (Ruslina, 2012). Without this partisanship, the economy only belongs to individuals, especially conglomerates who have large capital and are able to create large-scale businesses that are not friendly to small and new businesses that are more considered as rivals than as partners.

The role of Pasal 33 of Undang-Undang Dasar RI (UUD) 1945 to support entrepreneurship has also been recognized through the 1999 GBHN which emphasized that economic democracy works by developing the capabilities of cooperatives and small and medium enterprises (MPR, 1999). Also note that the MPR in this GBHN mentions entrepreneurship by placing it in the youth and sports section. In point $d$ of this section, it is stated that the government must "develop entrepreneurial interest and enthusiasm among young people who are competitive, superior and independent" (MPR, 1999). Meanwhile, in the education department, one of the points is that the government must "develop the quality of human resources as early as possible in a directed, integrated and comprehensive manner through various proactive and reactive efforts by all components of the nation so that the younger generation can develop optimally accompanied by the right of support and protection in accordance with its potential ". Entrepreneurship education is in line with the goals of national education, one of which is to create creative and independent human beings (Law No. 20 of 2003 concerning the National Education System article 3) (President of the Republic of Indonesia, 2003).

However, Indonesia has long been dominated by entrepreneurs. Throughout the Orde Baru, entrepreneurs get a fresh breeze. Small businesses grow but without support from the government. On the other hand, large companies get substantial support with various facilities and incentives. Economic democracy is defined as the benefit of individuals and 
individuals here of course are people with great power and funds. During that time, education functioning only to produce employee to work in these companies. Indonesia's education isn't familiar to make a student creating their own company. That's lead to famous term among the entrepreneur which are, "it's useless for college to only be an employee" or "don't need school to be rich". This is because the education system at that time functions to serve entrepreneurs, while entrepreneurs are forced to grow hard from real-life trial errors. Some of them, fall and cannot rise again, may fall into poverty or be forced to become employees of large companies.

What Indarti and Rostiani (2008) found when comparing factors that influence students' entrepreneurial intentions in Indonesia to Japan and Norway is not suprising. The study found that only in Indonesia educational factors became significant in determining the intention of entrepreneurship. Even stranger, the significant influence is negative. That is, the more students are taught business and economics, the lower the intention of student to become enterpreneur. This contrasts with the situation in Singapore, where student lean more about economic and business also increase their motivation to become entrepreneur. The worst part is, these negative influences contributed in addition to self-efficacy, in the intention of entrepreneurship by $28.2 \%$, the highest compared to Japan (14.2\%) and Norway $(24.8 \%)$. It is also natural for the two researchers to conclude that Indonesia curriculum has encouraged the student to become employees, rather than entrepreneurs, even though entrepreneurship is an inseparable field of economics and business.

Indeed, most of the big entrepreneurs start their own business from the beginning. But they did not learn this in the Indonesian education system. The decision comes from various backgrounds and their life dynamic as a process that were not captured in entrepreneurship education in Indonesia. Since Indonesia did not develop in the economic democratic system, these conglomerates lost the important spirit of togetherness and saw that other people with the same business, although far smaller, were competitors, instead of an aprentice to inherit knowledge or friends to share entrepreneurial experience.

The emergence of the concept of economic democracy in amendment to Pasal 33 of UUD 1945 is a major advance in enterprenualship. This concept has been supported by principles such as togetherness, efficiency, justice, sustainability, environmental insight, independence, and maintaining a balance of progress and unity of the national economy. Economic democracy guarantees that the economy is run together and together. Ideally, all citizens are given the opportunity to participate with his choice to become an entrepreneur or as an employee and other profession. With this choice, they can contribute to the maximum with the right choice and according to their background. This is what can be interpreted from the principle of efficiency brought by Pasal 33 of UUD 1945 paragraph 4. Unfortunately, often one door or all the doors are closed. For unemployed, the door as an employee has been closed. While for a scholar, perhaps the door of entrepreneurship has been closed, because during education they get a subjective norm if entrepreneurs are only for drop-outs, wasting higher education they have traveled, or because they cannot see opportunities due to various factors, including institutional factors. Therefore, the progress brought about in Pasal 33 of UUD 1945 paragraph 4 must be seen as a hollow step if the sense of togetherness and kinship implied by economic democracy is not felt by all nations.

These entrepreneurs now have a responsibility to be involved in entrepreneurship education. It has become their responsibility because of the economic system and the advantages they've get back when the principle hasn't adopted in the system. They have lo actualize the togetherness by contributing to the creation of new entrepreneurs armed with the knowledge they have acquired and benefits. It would be very helpful if these big entrepreneurs become mentors for students or at least become partners for universities to serve students in entrepreneurship education programs.

Ciputra is an exemplarysucsess story. $\mathrm{He}$ is a figure who continues to spread the entrepreneurial spirit in Indonesia. He was very intensive in developing entrepreneurship education in the colleges he built. This is an important example of how economic democracy 
should work in the spirit of brotherhood in Indonesia, in accordance with Pasal 33 UUD 1945 paragraph 4.

Employees have played an important economic role. Without these employees, entrepreneurs will not be able to grow big. They are the economic unsung heroes. Becoming an entrepreneur is a logical option to honor their hard work. Similarly, an entrepreneur must also be taught to appreciate his employees. This should be part of entrepreneurial education content, especially in developing and advanced types of entrepreneurship.

Entrepreneurship education that is currently developing at the national and local level still needs to be improved in order to produce maximum effects for reducing unemployment, increasing economic growth, and increasing the number of entrepreneurs for the common good in economic democracy. Various entrepreneurship education which is currently held in universities is still very fixated on theoretical and knowledge aspects, rather than aspects of experience. Education has been conducted masively so that students do not get individual guidance even if they really feel the need to take the path as an entrepreneur. They do not know when (know-when) and do not know who (know-who), and also do not know (knowhow). They only know (know-why) and what (know-what), as taught partially by entrepreneurship education in universities today. The education that is taught is still very common, not focusing on the typical aspects of the millennial generation that are information technology literate but impatient. Judging from the Zupan and Nabergoj entrepreneurship education model (2016), entrepreneurship education in Indonesia is only able to provide process components. Entrepreneurship education in Indonesia needs to be supported to be able to provide a component of the environment, which is a condition for student entrepreneurship continuity.

\section{CONCLUSION}

Entrepreneurship education in Indonesia has still not been able to produce the situation of unemployment and economic growth that Indonesia has achieved in the Orde Baru era. Meanwhile, the proportion of entrepreneurs is still far below neighboring countries and developed countries. Therefore, it is very necessary for entrepreneurship education to be encouraged better. The traditional mindset that still focuses on industrialist and individualistic perspectives needs to be increasingly directed at the principles of economic democracy that are passionate about family and mutual cooperation. The theoretical framework reviewed can be used to improve the current situation of entrepreneurship education in Indonesia.

\section{REFERENCES}

Berita Satu. (2016). Indonesia butuh lebih banyak wirausaha baru. Retrieved October 28, 2018, from http://www.beritasatu.com/nasional/365893-indonesia-butuh-lebih-banyakwirausaha-baru.html

Bin Yusoff, M. N. H., Zainol, F. A., \& Bin Ibrahim, M. D. (2015). Entrepreneurship education in Malaysia's public institutions of higher learning-A review of the current practices. International Education Studies, 8(1), 17-28. https://doi.org/10.5539/ies.v8n1p17

Blenker, P., Dreisler, P., \& Kjeldsen, J. (2006). Entrepreneurship Education - the New Challenge Facing the Universities (No. 2).

BPS. (2018a). Pertumbuhan Ekonomi 1986-2018. BPS.

BPS. (2018b). Tingkat Pengangguran Terbuka (TPT) Menurut Provinsi di Indonesia, 2-7.

Fayolle, A., Gailly, B., \& Lassas-Clerc, N. (2006). Effect and Counter-effect of Entrepreneurship Education and Social Context on Student's Intentions. Estudios de Economia Aplicada, 24(2), 509-523. https://doi.org/10.1103/PhysRevLett.98.065002 
Heinonen, J., \& Poikkijoki, S. A. (2006). An entrepreneurial-directed approach to entrepreneurship education: Mission impossible? Journal of Management Development, 25(1), 80-94. https://doi.org/10.1108/02621710610637981

Hindle, K. (2007). Teaching entrepreneurship at university: from the wrong building to the right philosophy. Entrepreneurship Education, (September), 104-126. https://doi.org/10.4337/9781847205377.00013

Indarti, N., \& Rostiani, R. (2008). Intensi Kewirausahaan Mahasiswa: Studi Perbandingan Antara Indonesia, Jepang dan Norwegia Intensi Kewirausahaan Mahasiswa: Studi Perbandingan Antara Indonesia, Jepang dan Norwegia. Jurnal Ekonomika Dan Bisnis Indonesia, 23(4), 1-27. https://doi.org/10.22146/jieb.6316

Jones, B., \& Iredale, N. (2010). Enterprise education as pedagogy. Education + Training, 52(1), 7-19. https://doi.org/10.1108/00400911011017654

Jones, C., \& English, J. (2004). A Contemporary Approach to Entrepreneurship Education. Education+ Training, 46(8/9), 416-423.

Kominfo. (2017). Peluang Besar Jadi Pengusaha Di Era Digital. Retrieved October 28, 2018, from https://kominfo.go.id/content/detail/9503/peluang-besar-jadi-pengusaha-di-eradigital/0/berita

Kuratko, D. F. (2005). The Emergence of Entrepreneurship Education: Development, Trends, and Challenges. Entrepreneurship Theory and Practice, 577-598.

Lackéus, M., Lundqvist, M., \& Middleton, K. W. (2016). Bridging the traditional-progressive education rift through entrepreneurship. International Journal of Entrepreneurial Behaviour and Research, 22(6), 777-803. https://doi.org/10.1108/IJEBR-03-2016-0072

Liñán, F. (2004). Intention-based models of entrepreneurship education. Piccola Impresa/Small Business, 3(1), 11-35.

Minniti, M., \& Lévesque, M. (2008). Recent developments in the economics of entrepreneurship. Journal of Business Venturing, 23(6), 603-612. https://doi.org/10.1016/j.jbusvent.2008.01.001

Moberg, K. (2014). Two approaches to entrepreneurship education: The different effects of education for and through entrepreneurship at the lower secondary level. International Journal of Management Education, 12(3), 512-528. https://doi.org/10.1016/j.ijme.2014.05.002

Mopangga, H. (2014). Faktor Determinan Minat Wirausaha Mahasiswa Fakultas Ekonomi dan Bisnis Universitas Negeri Gorontalo. Jurnal Ekonomi Trikonomika, 13(1), 78-90.

MPR. (1999). TAP MPR No. IV/MPR/1999 tentang GBHN 1999-2004, (Iv), 1079-1105.

Perren, L., \& Jennings, P. L. (2005). Government discourses on entrepreneurship: Issues of legitimization, subjugation, and power. Entrepreneurship: Theory and Practice, 29(2), 173-184. https://doi.org/10.1111/j.1540-6520.2005.00075.x

Prahara, H. (2017). Ekonomi Digital, Masa Depan Kewirausahaan Indonesia. https://doi.org/10.1111/j.1469-7610.2010.02280.x

Presiden RI. Undang-Undang RI No 20 Tahun 2003 tentang Sistem Pendidikan Nasional (2003)

Rae, D. (2010). Universities and enterprise education: Responding to the challenges of the new era. Journal of Small Business and Enterprise Development, 17(4), 591-606. https://doi.org/10.1108/14626001011088741

Ruslina, E. (2012). Makna Pasal 33 Undang-Undang Dasar 1945 Dalam Pembangunan Hukum Ekonomi Indonesia. Jurnal Konstitusi, 9(1), 48-82.

Volkmann, C., Wilson, K. E., Partners, G. V, Mariotti, S., Rabuzzi, D., Vyakarnam, S., ... Sepulveda, A. (2009). Educating the Next Wave of Entrepreneurs - A Report of the Global Education Initiative At the World Economic Forum.

Zupan, B., \& Nabergoj, A. S. (2016). Incorporating design thinking in entrepreneurship education. European Conference on Innovation and Entrepreneurship, (2004), 876-883. 